\title{
Los donativos de la ciudad de Sevilla durante el reinado de Carlos II
}

\author{
Manuel Escalona Jiménez*
}

\begin{abstract}
RESUMEN
La petición de cantidades extraordinarias de dinero bajo la denominación de donativos, para atender a los gatos derivados sobre todo del mantenimiento de las tropas durante las campañas militares y el abastecimiento de la Armada, fue una costumbre puesta en práctica a partir del reinado de Felipe /ly continuada por sus sucesores.

En el reinado de Carlos II se quiso suavizar la presión fiscal, eliminando las peticiones extraordinarias de dinero.

Pero cuando surgian los conflictos bélicos el único recurso posible era el donativo, pues el resto de las cantidades recaudadas estaban ya empeñadas en otros menesteres.

La ciudad de Sevilla, que se había caracterizado por la generosidad de los donativos ofrecidos al rey, no disponia ya durante la época de Carlos II del poder económico de antaño y tenía grandes dificultades para recaudar las cantidades ofrecidas y hacer frente al mismo tiempo a los donativos del reinado anterior aún pendientes, ya que los arbitrios que se imponían no daban el fruto apetecido.
\end{abstract}

\section{ABSTRACT}

The request for an extra amount of money, called donativo, in order to meet the expenses originated by the maintenance of troops during military campaigns and the supplying of the Navy, was a practice held from Philipp II's reign and continued by his sucessors.

In Charles II's reign, a lessening of tax pression was intended, by means of removing the requests of extra money. But, in the occasion of war conflicts, the only possible resources were the donativos, because the other taxes had been already used for other needs. Seville, which would stand out for the generosity of its donativos, had not the same economic power as in past times, and was in great trouble to collect the money for the new and the old financial help granted to the king, because the taxes did not produce the expected results. Therefore, at the end of the seventeenth century there was no other solution but reducing to the maximum this way of extra contribution to the Monarchy.

* UNED. 
Por lo tanto, al final del siglo xvil no

quedó otra solución que la de limitar al

máximo esta forma de contribución

extraordinaria a la Monarquía.

La petición de sumas de dinero con carácter extraordinario a los reinos de Castilla bajo el nombre inexacto de "donativo" fue una práctica puesta en circulación a partir del reinado de Felipe II y que se prolongaría durante la monarquia de los Austrias, perdurando hasta la entrada de los Borbones. Naturalmente era una fórmula utilizada sólo en casos excepcionales de extrema urgencia de la Monarquía, siempre por motivos de carácter militar.

Como es bien sabido, la activa política exterior llevada a cabo por la Monarquía española tenía que desembocar obviamente en la necesidad de disponer de más ingresos, pues los fondos recaudados, pese al crecido número de impuestos existentes, cubrían escasamente los gastos ordinarios y, cuando surgía algún contratiempo que requiriera un nuevo aporte de dinero, no había otra opción que recurrir a expedientes extraordinarios como los donativos.

Al hacerse cargo Felipe II de la Corona de Castilla tuvo que reorganizar las finanzas, aunque siguió el modelo heredado del pasado, de los tiempos del Emperador e incluso de la época bajomedieval. Los ingresos tenían distintas procedencias, como las rentas provinciales (alcabalas, cientos, tercias, etc.), las rentas generales (almojarifazgos, aduanas), los servicios de Cortes, las concesiones eclesiásticas (subsidio, cruzada, excusado), además de otros extraordinarios. Pero las recaudaciones no eran suficientes para lo abultado de los gastos. El costo de las guerras exigía el mayor esfuerzo del erario público, pues no sólo había que atender a la organización de los ejércitos que combatían en los campos de batalla de Europa, sino que había que costear el servicio diplomático, el espionaje y los correos, la construcción de fortificaciones, la marina de guerra, aparte de los derivados del mantenimiento del orden interno y el afianzamiento de la autoridad del monarca, la administración pública y el funcionamiento de una casa real en constante aumento. Las necesidades de numerario fueron tantas que a veces hubo de recurrirse a recaudaciones extraordinarias, entre ellas a los donativos, aunque Felipe II fue muy comedido en su empleo, pues el primero, el que inagura la serie, no fue solicitado hasta1590, y recibió buena acogida por parte del clero y los grandes nobles ${ }^{1}$.

Las obras de CARANDE, Ramón: Carlos $V$ y sus banqueros. Madrid, 1964, y de UlloA, Modesto: La hacienda real de Castilla en el reinado de Felipe II. Roma, 1963, constituyen los estudios más completos sobre la política fiscal en este periodo. 
La España heredada por Felipe III en 1598 era un vastísimo organismo provisto de recursos sin duda ingentes, pero que se hallaban muy dispersos y amenazados por numerosos enemigos, por lo que no eran directamente movilizables para mantener los compromisos de la Corona. El problema era doble, pues por un lado se debía convertir los recursos en ingresos fiscales disponibles por parte del soberano, y por otro habia que atender con los fondos existentes los excesivos gastos. Como llegó un momento en que resultó imposible recurrir a nuevas imposiciones sobre unos contribuyentes ya muy recargados de gravámenes, el monarca empleó otras modalidades ya conocidas para la obtención de fondos, como fue la venta de los oficios públicos y de las alcabalas o la legalización del tráfico con los holandeses y los hanseáticos, pero sobre todo continuó con los servicios de millones, que, aunque gustaban poco al Consejo de Hacienda y a todo el entorno regio, resultaban un expediente útil para salir del paso, pese a las constantes protestas que su imposición levantó en el reino y a las voces que se elevaron clamando por su supresión ?

Felipe IV y su valido, el conde-duque de Olivares, siguieron empeñados en la defensa de la reputación, pero el estado de las finanzas que les habia dejado su antecesor no permitía demasiadas aventuras, ya que las rentas estaban vendidas y empeñadas por varios años. Ante la resistencia de los ricos a colaborar con la hacienda, no les quedó más solución que echar mano de otros medios, prodigando el impuesto de los millones y la acuñación de la moneda de vellón o incluso de puro cobre, además de los "ensanches" $y$ "quiebras" para resacirse de los bajos ingresos de las tasas sobre los cuatro productos tradicionales, carne, vino, aceite y vinagre. Aun así, en más de una ocasión tuvieron que recurrir a las recaudaciones extraordinarias, como el donativo, sobre todo ante la necesidad imperiosa de numerario generada por los conflictos internacionales, como fueron las guerras de los Paises Bajos y de los Treinta Años, asi como por los conflictos internos de Portugal y de Cataluña, y también por la reforma de la Armada para el mantenimiento del Imperio americano.

La hacienda dejada por Felipe IV a Carlos II se encontraba en un estado lamentable, pese a que en su reinado se habían creado más tributos que en los de todos sus predecesores juntos. Así, al comenzar el nuevo reinado, la regente Mariana de Austria tomó la decisión de no reunir más las Cortes, por lo que el Consejo de Castilla fue el organismo determinante en la polít-

2 Gelabert, Juan E.: La boisa del Rey. Rey, reino y fisco en Castilla (1598-1648). Barcelona, 1997. En esta obra se puede encontrar el análisis más detallado de la evolución de la hacienda durante el reinado de Felipe III. 
ca fiscal. Un organismo que se reveló poco amigo de solicitar donativos, ya que las arcas de las ciudades estaban vacías y además quedaban por cumplir los pagos de varias cantidades ofrecidas durante el periodo anterior. Por otra parte, los dos principales ministros, el duque de Medinaceli y el conde de Oropesa, con el marqués de los Vélez al frente del Consejo de Hacienda, estaban muy interesados en poner al día la hacienda española haciendo contribuir a las clases privilegiadas en orden a su riqueza real. El fracaso de este reformismo hacendístico motivó el mantenimiento del recurso a los donativos, necesarios sobre todo para continuar con la reconstrucción de la Armada y para atender a los conflictos surgidos en el escenario europeo, asi como para garantizar la defensa de la frontera con Portugal.

Sin que existiera una regla fija, el procedimiento se ponía en marcha cuando surgía la necesidad. El Consejo de Castilla proponía una suma total y hacía un reparto de las cantidades a contribuir por parte de los distintos reinos, los cuales a su vez las distribuian entre las ciudades que lo componían, que se reservaban una parte como aportación propia y repartían el resto entre las villas de su partido según sus posibilidades económicas, en atención a la superficie de su término municipal, riqueza agropecuaria y número de habitantes.

Tampoco existía una forma de recaudación prevista, aunque era ésta una cuestión que poco importaba al Consejo de Castilla. Normalmente, se echaba mano de las imposiciones tradicionales ya utilizadas para otras recaudaciones, como eran poner arbitrios especiales a la entrada y salida de productos, alquilar las tierras de propios y baldios pertenecientes a las ciudades y villas o hacer un reparto de cantidades entre los vecinos. Aunque se pretendía rehuir esta última modalidad, no siempre era posible, sobre todo cuando los arbitrios impuestos no daban los beneficios esperados o cuando la premura del tiempo concedido para su entrega al receptor del donativo obligaban a esta imposición directa, dándose incluso el caso de colocarse un párroco, un regidor y un escribano los días de fiesta en la puerta de la iglesia para pedir a los feligreses pudientes, o el de pasar las autoridades de la ciudad casa por casa a pedir a modo de limosna.

Otro sistema puesto en práctica para conseguir las cantidades extraordinarias fue gravar a las personas físicas, bien por razón de su profesión (médicos, abogados, mercaderes, etc.), de acuerdo con sus propiedades (grandes, títulos, clero, etc.) o simplemente a funcionarios en proporción a la importancia de su empleo (escribanos, jueces, alcaldes, regidores, etc.) ${ }^{3}$.

3 Para hacer un estudio a fondo dei tema se pueden consultar las obras siguientes: DominGUez ORTIZ, Antonio: Política y Hacienda de Felipe $N$, $1^{z}$ edición. Madrid, 1963; Id.: Política fiscal y cambio social en la España del siglo XVII, Madrid, 1984; SÁNCHEZ BELÉN, Juan Antonio: La politica fiscal en Castilia durante el reinado de Carlos II. Madrid, 1996, y GARZON PAREJA, Manuel: La 
El reino de Sevilla se había distinguido desde el principio como la principal fuente de ingreso de toda Castilla, debido a su importante comercio con América, así como a sus relaciones con otros mercados españoles y europeos, circunstancia que hizo decir al conde-duque de Olivares en su famoso Gran Memorial: «aquel lugar sin duda el más principal de estos reinos, valiéndose a V.M. más de un tercio que todos los reinos de Castilla juntos". Aunque posteriormente manifestara Luis de Haro, nuevo valido del rey, que "el municipio sevillano era más largo en prometer que en cumplir» 4.

El siglo xvı se inició para la ciudad de Sevilla con un esplendor más ficticio que real, transformándose de un centro urbano importante pero de irradiación limitada, a otro de atracción de una muchedumbre heterogénea de comerciantes, banqueros, artistas, marinos, etc., pero también de maleantes, mendigos y aventureros; de una metrópoli regional con industrias locales pasó a sede de un comercio de largo alcance, regional, internacional y ultramarino. La base económica de la Sevilla de principios del siglo Xvi era la agricultura, no porque sus moradores se dedicaran a esta labor, sino porque las rentas de la ciudad procedían principalmente del clero y patriciado que vivían de sus extensos dominios. Esta aparente prosperidad se empañaba de vez en cuando con episodios adversos debido a inundaciones o pestes, acompañados de carestía y escasez en los alimentos. Pero lo más negativo fue la expulsión de unos 7500 moriscos en 1610 , lo que dio lugar a la salida de una mano de obra necesaria para el desarrollo de la ciudad y que sobre todo pagaba sus impuestos. Por contra, continuaban llegando los galeones cargados de plata que luego se transformaban en monedas para terminar en los más alejados paises, lo que convirtió a ciudad en el primer mercado dinerario de España con la consiguiente acumulación de capitales y fomento de la actividad industrial para rebasar el estrecho límite de la artesanía.

El periodo de máxima prosperidad tuvo lugar durante los reinados de Felipe II y de Felipe III, aunque ya en los primeros decenios del siglo XVII se observaran sintomas de declive. En la visita realizada a la ciudad por Felipe IV en 1624, su valido, el conde-duque de Olivares, pudo apercibirse

Hacienda de Carlos II. Madrid, 1980. También el artículo de Dominguez Ortiz, Antonio: «La desigualdad contributiva en Castilla durante el siglo Xv|l», Anuario de Historia del Derecho Español. Madrid, XXI-XXII,1951-1952.

4 Dominguez Ortiz, Antonio: «Sevilla y la Hacienda de los Austrias: el encabezamiento de las alcabalas", Hacienda Pública Española. Madrid, n²69, págs. 67-76. 
del estado de pobreza de Sevilla, aunque no quedaron mejoradas las cosas, pues se impusieron nuevas cargas a la hacienda municipal. Este declive fue acentuado por la peste de 1649, que produjo unos 60000 muertos y de la que no volvió a recuperarse, y por las dificultades crecientes del tráfico marítimo por el Guadalquivir (cauce irregular del río y acumulación de aluviones que impedían en muchas ocasiones la navegación de los barcos entre 200 y 500 toneladas, los más frecuentes durante el siglo XVII), permitiendo el ascenso de Cádiz.

En esta situación poco brillante llegó el reinado de Carlos II, que, aunque pasó por ser uno de los más nefastos de nuestra historia, significó sin embargo para Sevilla un período de relativa mejoría sobre todo al final del siglo, debido a una menor presión fiscal, como se observa al analizar las crónicas hispalenses de aquellos años, donde los bandos publicados tenían por finalidad principalmente paliar las carencias más acuciantes producidas por las calamidades, como el terremoto de 1680 , la peste o la sequía ${ }^{5}$.

Esta Sevilla decadente y empobrecida hubo de atender durante el reinado de Carlos II no sólo a los donativos solicitados por el monarca reinante, sino a los concedidos anteriormente a Felipe IV, que no habían quedado totalmente devueltos a la finalización de su reinado, por lo que su liquidación había quedado pospuesta a este período.

El siguiente cuadro presenta las concesiones de nuevos donativos y los atrasados aún no sufragados que la ciudad de Sevilla tuvo que asumir durante los años tratados:

\footnotetext{
Para conocer la situación de la ciudad de Sevilla en el siglo XVII: Dominguez OrTIZ, Antonio: Orto y Ocaso de Sevilla. Sevilla, 1946; id. Historia de Sevilla. La Sevilla del siglo XVII. Sevilla, 1986.

En el libro de Aguado de los Reyes, Jesús: Riqueza y Sociedad en la Sevilla del siglo xVII. Sevilla, 1994, se hace una clasificación de la sociedad sevillana según el siguiente orden:

- La nobleza, de clase media y baja, destacando la presencia de los veinticuatros sin fortunas escandalosas, pero que ocupaban los altos puestos del gobierno de la ciudad.

- El clero, catalogado como pobre y dentro del más bajo escalón social, sólo por encima de los artesanos.

- Los mercaderes, el grupo más dinámico y variopinto de Sevilla gracias al tráfico con Indias, con gran peso social.

- Funcionarios y profesionales libres (mesocracia), de posición desahogada, pero dependiendo de la evolución de la coyuntura económica.

- Artesanos, con escasa capacidad económica, muchos de ellos clasificados en la categoria de pobres.

- Propietarios agrícolas, situados entre los escalones más bajos de la sociedad y con gran nivel de endeudamiento.

- Indeterminados: rentistas, pobres de solemnidad, viudas, etc., con mezcla de toda clase de situaciones.
} 


\begin{tabular}{|c|c|c|}
\hline Fecha & Cantidad & Finalidad \\
\hline & & Procedentes de Felipe IV \\
\hline 1643 & 80.000 ducados & Defensa de la frontera de Portugal ${ }^{6}$ \\
\hline 1662 & 60.000 ducados & Apresto de la Armada de la Mar Océana ${ }^{7}$ \\
\hline \multirow[t]{2}{*}{1664} & 150.000 ducados & $\begin{array}{l}\text { Defensa de los reinos, conquista de Portugal y pagas y so- } \\
\text { corros de las tropas llegadas de Italia y Alemania }{ }^{8}\end{array}$ \\
\hline & & Concedidos a Carlos II \\
\hline 1671 & 75.000 ducados & Provisión de Flandes y Principado de Cataluña ${ }^{9}$ \\
\hline 1671 & 70.000 ducados & Apresto de la Armada 10 \\
\hline 1674 & 75.000 ducados & Asistencia a Flandes, Cataluña y diversos presidios ${ }^{11}$ \\
\hline 1674 & 100.000 escudos & $\begin{array}{l}\text { Apresto de la Armada y ejércitos de Flandes y del Principado } \\
\text { de Cataluña }{ }^{12}\end{array}$ \\
\hline 1676 & 80.000 escudos & Guerra con Portugal ${ }^{13}$ \\
\hline 1684 & \multirow{2}{*}{\multicolumn{2}{|c|}{$\begin{array}{l}\text { Donativo real a personas de oficio }{ }^{14} \\
\text { Dos compañias con } 120 \text { hombres para la campaña de Cataluña } 15\end{array}$}} \\
\hline 1690 & & 20 hombres para la campaña de Cataluña ${ }^{15}$ \\
\hline
\end{tabular}

A.M.S., Sección 4a, Escribanías de Cabildo, tomo 13, documento 50.

Ibidem, tomo 13, documento 45: «A Sevilla y su tierra le tocó pagar de su alcabala para el donativo del apresto de la Armada de la Mar Océano con 60000 ducados de los 600000 que el reino ofreció".

8 A.M.S., Sección 1ª Privilegios, carpeta 10, documento 192: «El ayuntamiento ha ofrecido 150000 ducados de vellón al rey N.S. para acudir a la defensa de nuestros reinos y conquista de Portugal, asistir a las pagas y socorros de las raciones que van viniendo de Italia y Alemania".

9 lbidem, documento 185: "Para la precisión de los gastos que se le ofrecen por las provisiones de Flandes y Principado de Cataluña y de otros servicios por acuerdo de 17 de marzo de 1671 haber ofrecido servicios por vos y vuestros vecinos con 75000 ducados del nuevo y último donativo de un millón con que se hace mandado nos sirvan las ciudades, villas y lugares de estos reinos, señoríos y vecinos particulares".

10 A.M.S., Sección 10a, Actas Capitulares, siglo XVII, tomo 146. Poco después del anterior la ciudad volvió a conceder otro donativo de 50000 ducados, parte de los 500000 que sirvió el reino para "el apresto de la Armada y para que salga con la mayor rapidez". Posteriormente fue aumentado en 20000 ducados, dando los 70000 ofrecidos definitivamente.

11. Ibidem: “En cabildo celebrado el día 12 de febrero de ese año la ciudad ofreció 75000 ducados parte del millón que tocaron al reino para la asistencia a Flandes, Cataluña, presidios y fronteras".

lbidem: "Los 100000 escudos prontos para la Armada Real del Océano, en cuya consideración y del estado presente del rompimiento de la guerra con Francia y precisión de sus asistencias de los Ejércitos de Flandes y Principado de Cataluña en que reconoce la importancia de engrosarlo y mantener y servir los presidios y fronteras en una y otra parte y la disposición esta primavera para guardar las costas y comercio con Indias. Por ello se sirve a S.M. con los 100000 escudos de vellón que se de para este efecto, los cuales se han de buscar y tomen luegos prestados de los arbitrios"

13 A.M.S., Sección 4a, Escribanías de Cabildo, tomo 13, documento 42. En cabildo de 11 de noviembre de ese año "al rey don Carlos la ciudad le ofrece con motivo de la guerra con Portugal 80000 escudos para sustentar dos meses 5000 infantes que protegiesen las fronteras de ese reino y el repaso de sus costas, en las mismas condiciones prorrogadas de 1644".

${ }_{14}$ Ibidem, documento 51 . Consistía en que las personas que tenían un oficio público debian entregar unas cantidades fijas según el valor de su título, que eran destinadas a gastos varios.

15 A.M.S., Sección 10 . Actas Capitulares, siglo XVII, tomo 155: “la ciudad con su gran celo sirvió con dos compañías de 120 hombres el año pasado de 1690 para la campaña de dicho año en el frente de Cataluña y que continuando en su celo reclutó otra en 1691 una para relevarlas". 
Una vez que el ayuntamiento de la ciudad admitía la cantidad ofrecida - asignada para hacer frente al donativo que debía entregar el reino de Sevilla, había que buscar la forma de hacerse con el dinero, toda vez que nunca el municipio tenía un fondo en depósito ni recursos previstos para obtenerlos.

Por ello se echaba mano de las únicas posibilidades existentes. Una, la imposición de arbitrios a los productos que entraban y salian de la ciudad, fórmula que por otro lado ya se usaba para las recaudaciones corrientes de impuestos, de modo que el gravamen consistía en el aumento de las cantidades que recargaban los precios de los productos. Otra, el arrendamiento de las tierras de propios y baldíos, privando a los vecinos de su utilización común para el pastoreo del ganado y otros usos. Como última opción, quedaba la derrama, repartiéndose parte de la cantidad entre las villas del partido en función de sus medios económicos. El ayuntamiento podía elegir los recursos que creyera más convenientes para obtener los fondos, pero siempre tenía la obligación de presentar la propuesta al rey, ya que era necesaria su aprobación para proceder a la puesta en práctica de la fórmula elegida. Lo normal era la aceptación real, pero en algunos casos, sobre todo en el del arrendamiento de propios y baldíos, la propuesta podía ser rechazada.

El recurso más empleado, por ser el más práctico, consistió en la imposición de arbitrios especiales sobre el consumo y el comercio, a veces sobre productos básicos, pero especialmente sobre artículos considerados de lujo. Debian ser productos bien controlados por las aduanas o procedentes de un mismo lugar, como era el caso de la carne (todas las reses se sacrificaban en el matadero y después se repartían por las carnicerías de la ciudad). En realidad las imposiciones establecidas para recaudar los fondos eran las mismas de siempre, siendo frecuente que en sucesivos donativos se gravaran productos que lo estaban todavía de la imposición anterior.

Para el donativo de 80.000 ducados de 1643 , ofrecido para la defensa de la frontera de Portugal, se impusieron dos ducados por saca de lana, un real en cada cuero y medio real en cada libra de añil (posteriormente fue modificado en un real por arroba de lana, real y medio en cada cuero y medio real en cada libra de añil), cantidades que se hacían efectivas en la aduana de la ciudad y en las demás existentes en su distrito ${ }^{16}$. Estos mismos arbitrios, los rectificados, se repitieron en 1676 con los 80.000 escudos para asistir también a la guerra contra Portugal.

16 A.M.S., Sección 19, Privilegios, carpeta 27, documento 381. 
Otros arbitrios consistieron en el cuatro por ciento de la ropa y el uno por ciento de todos los géneros que entrasen por la aduana de la ciudad. Fue la fórmula utilizada para obtener los 60.000 ducados de 1662 destinados al apresto de la Armada ${ }^{17}$. Fue poco empleado y sólo se usó otra vez, junto a otro grupo más numeroso de artículos, en los 150.000 ducados ofrecidos en 1664 para distintos gastos de guerra:

«la ciudad se sirvió poner por via de arbitrio dos cuartos en cada libra de azúcar de la que se consumiere en esta ciudad y sus arrabales o saliese de ella para cualquier parte, cuya deuda se causare a la entrada, un cuarto en cada almud o celemín de cebada que se consumiere en los mesones y posadas de esta ciudad y sus arrabales, medio real en cada libra de chocolate y cacao que saliese de ella; de cada carga de ropa o mercadería de cualquier género que saliese de esta ciudad y sus arrabales, vendida o no vendida o para venderse, si fuera cabalgadura menor, dos reales y si mayor cuatro; si de carro o carreta de bueyes, un ducado, y si de galera o carreta de mulas, dos ducados, menos las cargas y carretas que saliesen de granos o municiones de cuenta de S.M. y otras que sean del Real Servicio y de su cuenta; y últimamente de cada arroba de aceite que se sacase por el río, puertos y embarcaderos de esta ciudad y su jurisdicción por cualquier parte que fuere, como no sea para las Indias, un real»" 18.

En el donativo de 1674 de 100.000 escudos para el apresto de la Armada, autorizó el rey, "para no molestar a los vecinos", que se prorrogasen estos mismos arbitrios, pero sólo los que recaian sobre el cacao, chocolate, azúcar y aceite "que se cargasen para fuera del reino y que no fueran para América y sobre las cargas que se sacasen también en carretas y carros de la ciudad y sus arrabales" 19 . Esto fue posible porque en 1674 , de los 150.000 ducados del anterior impuesto sobre estos productos (adelantados a préstamo por un particular con un interés del diez por ciento), ya se habían devuelto 110.000 ducados, por lo que podían añadirse los 100.000 escudos cargando ahora el gravamen sólo sobre estos cinco artículos ${ }^{20}$.

En los 75.000 ducados de 1671 para atender a la campaña de Flandes, Cataluña y otros servicios, el ayuntamiento no pudo usar los arbitrios vistos hasta ahora y que eran los tradicionales, por estar empeñados por mucho tiempo, así que tuvo que elegir otros nuevos, como

“imponer y cobrar un real en cada arroba de vino del Aljarafe y Banda Morisca, real y medio en cada arroba de vino de la sierra de todo lo que en-

Ibidem, carpeta19, documento 69.

A.M.S., Sección 19, Privilegios, carpeta10, documento 188.

A.M.S., Sección 10ª , Actas Capitulares, siglo XVII, tomo 146.

Ibidem. 
trase en la ciudad y sus arrabales, medio real en cada arroba de aceite, un real en cada botija de vino, veintidós reales en cada pipa de vino que se carguen en dicha ciudad o salieren por el río para fuera del reino".

Todos los arbitrios fueron aceptados por el monarca, excepto los que gravaban los productos sacados del reino ${ }^{21}$. Nuevamente tuvo que hacer la ciudad uso de estos mismos expedientes para el pago de los $75.000 \mathrm{du}$ cados de 1674 ofrecidos para las guerras de Cataluña y Flandes, dado el buen rendimiento que se estaba obteniendo, aunque todavía no se había liquidado el donativo de $1671^{22}$.

El último recurso empleado fue la imposición de dos maravedíes en cada libra de carne y de tocino pesada en las carnicerías públicas de la ciudad, con objeto de hacer frente a los 70.000 ducados de 1671 para el apresto de la Armada, aunque como sobre la carne recaían ya muchos impuestos, se cargaron 20.000 ducados sobre el vino que entrase en la ciudad a medio real por botija. Este nuevo recargo sobre la carne hizo que los vecinos acudieran a comprarla en los ventorrillos extramuros de la ciudad, donde no se pagaban los arbitrios y era por lo tanto más barata, cayendo la venta y por lo tanto la recaudación. Se tomaron varias medidas para evitar esta situación, como la de pedir certificación al matadero de la ciudad de las ventas a las carnicerías o vigilar su despacho en los ventorrillos, quitando las justicias la carne alli comprada a los que entraban por las puertas de la ciudad. Hubo además una queja de los criadores de ganado sobre robo de reses, que eran después sacrificadas y vendidas de forma clandestina. La solución final fue que también contribuyeran los ventorrillos con los mismos arbitrios ${ }^{23}$.

El arbitrio de la carne no se volvió a cobrar hasta 1690 con motivo de las dos compañías a caballo ofrecidas por la ciudad para colocarlas en la frontera de Cataluña con Francia. Como el prestamista no podía recuperar la cantidad adelantada sobre este arbitrio por las muchas cargas que ya tenía, quiso resacirse a partir de la entrada de nieve traída desde Ronda, que en aquel tiempo era utilizada como medicina para los enfermos, recurso que a pesar de las quejas de los vecinos y del ayuntamiento fue autorizado por Carlos $\mid{ }^{24}$.

Otro medio empleado por el ayuntamiento de la ciudad para hacerse de las cantidades ofrecidas fue el arrendamiento de los propios y baldíos,

\footnotetext{
A.M.S., Sección 1, Privilegios, carpeta 10a, documento 192.

A.M.S., Sección 10 , Actas Capitulares, siglo XVII, tom:o 146.

Ibidem, tomo 145.

Ibidem, tomo 155.
} 
dos tierras comunales propiedad de la ciudad y para uso de todos los vecinos, ya fuera para pasto del ganado, extracción de leña u otras actividades. Sólo se recurría a este sistema cuando la imposición de arbitrios era insuficiente para conseguir los fondos, ya que era un método que gozaba de poca simpatía por parte del Consejo de Castilla, que solía rechazar la petición de su empleo por parte del ayuntamiento.

Así ocurrió en 1674 con motivo del donativo de 150.000 ducados. La Corona autorizó el arriendo de forma parcelada o «rompimiento» de las tierras de Tablada, propias de la ciudad, ya que "tanto le ha costado a dicha ciudad y que no sirven en ese momento más que a los lugares que lindan con dichas tierras que se aprovechan sobre todo la villa de Berrocal cuyos vecinos se han encontrado con los pastos sin pagar tributos. Los otros baldios de los lugares no se deben dar a contribuir pues traerá la ruina a los criadores de ganado y la subida de la carne a la ciudad" ${ }^{25}$. En esta ocasión el ayuntamiento tuvo suerte, porque en la petición hecha en este mismo sentido en el año 1679 para acabar de pagar las cantidades adelantadas por particulares con motivo del donativo de 70.000 ducados del año 1671 fue rechazada ${ }^{26}$. Ya no se intentó el arrendamiento de las tierras de Tablada hasta el año 1692 con motivo del ofrecimiento hecho por la ciudad para componer y mantener dos compañias a caballo para la frontera de Cataluña. Se alegó que tenía la finalidad de sembrar granos para aliviar la escasez en los vecinos y que el descanso y pastoreo del ganado se podía realizar en otra dehesa contigua, también propia del ayuntamiento ${ }^{27}$.

El último recurso puesto normalmente en práctica era el de asignar parte de la cantidad donada por la ciudad a las villas pertenecientes a su partido. Esta decisión correspondía al cabildo sevillano y se hacía en función de la capacidad contributiva de los vecinos y ayuntamientos según la riqueza de sus tierras. El sistema de recaudación utilizado por las villas no le interesaba demasiado al gobierno de la ciudad, que sólo quería el ingreso de las cantidades asignadas, aunque los alcaldes debían comunicar las medidas adoptadas para su aprobación por el rey. En general poco amigos de hacer imposiciones directas a los vecinos por encabezamiento, los alcaldes, como además los productos sobre los que se podian recargar los arbitrios eran escasos, solían decidirse por el arrendamiento de los

A.M.S., Sección $10^{\circ}$, Actas Capitulares, siglo xVII, tomo 146.

A.M.S., Sección 1a Privilegios, carpeta 19, documento 69 .

lbidem, carpeta 29, documento 460 . 
propios y los baldíos de las villas, medida que en muchas ocasiones se llevaba a cabo antes de la aprobación real.

Para el donativo de 60000 ducados del año 1662, en el repartimento hecho a las villas, Constantina contribuyó con 464835 maravedies ingresados en ocho pagos. Como su situación económica no era buena, los vecinos pudientes tuvieron que adelantar las cantidades necesarias, que les serían devueltas sin intereses ${ }^{28}$. Sin embargo, en Puebla del Río, que debía colaborar con 65.000 maravedíes, aunque no había llegado todavía la aprobación real, el alcalde decidió arrendar de sus propios 100 fanegas para sembrar de cebada en el sitio denominado Caño de las Yeguas, además de tomar para ese fin el pago que hacía el convento de las Cuevas por la renta de la Dehesa Nueva ${ }^{29}$.

Para los 150.000 ducados del año 1664, la cantidad asignada a Alcalá del Río fue de 2.083.056 maravedíes, suma a reunir mediante el cobro de "un real en cada arroba de vino y aceite, medio real en cada arroba de vinagre, veinticuatro cuartos en cada fanega de cal, cuatro maravedies en cada libra de jabón y cuatro reales en cada libra de tabaco del que se comercie con la ciudad y su término, además de todos los dichos dineros para que se pudieren arrendar para pastos las dehesas de Matacruz, la Ruana, el Priesco, Cabeza Hermosa, Caela, el baldío de junto a los Molinos y algunas fincas más» ${ }^{30}$.

En los siguientes 100000 escudos de 1674, la villa de Aznalcázar debía aportar 65000 maravedíes. El asistente de la ciudad, Pedro Ramírez de Arellano, "dio licencia al Consejo, Justicia y Regimiento de la villa para que pueda arrendar por el tiempo necesario la dehesa llamada el Carrascal que es Propia de los vecinos, debiendo sembrarse de la forma ordenada como en otras ocasiones, sacándola a pregón y haciendo remate público ante el escribano, que debía ser aprobado por el Consejo de la villa y se le debía otorgar escritura pública a la persona o personas que la arrendasen por el tiempo necesario para sacar la cantidad repartida y sus gastos". Al final fue alquilada por cuatro años, pudiendo ser sembrada durante dos años y debiendo permanecer los otros dos en barbecho, aunque los arrendadores no debieron ser muy puntuales en el pago de las cantidades comprometidas, ya que tuvieron que ser apercibidos ${ }^{31}$.

Sin embargo, el ayuntamiento de Las Cabezas de San Juan, que se había comprometido con 115.872 maravedies, pese a la autorización de

${ }^{28}$ A.M.S., Sección $2^{\mathrm{a}}$, Contaduría, carpeta 153, documento 1.

29 Ibidem, documento 2.

3o A.M.S., Sección 13, Privilegios, carpeta 28, documento 407 .

31 A.M.S., Sección $4^{a}$, Escribanía de Cabildo, tomo 13 , documento 46. 
imponer arbitrios, no hizo uso de esa facultad, por lo que tuvo que buscar otro modo de conseguir el dinero. En primer lugar aceptó un asiento de 10000 reales ofrecidos por el marqués de la Fuente del Sol que unió a los 218 pesos que disponía de fondo en la caja de la villa. Como la cantidad era insuficiente para completar la cifra comprometida, en segundo lugar tuvo que proceder al arrendamiento de las dehesas de sus propios, denominadas Arenosa, La Botija y Majuelos, a cuatro reales de plata la fanega por el término de cuatro años ${ }^{32}$.

El donativo solicitado a las personas de oficio, concretamente el fijado para el año de 1684, fue determinado por el Consejo de Castilla para todos los reinos y consistía en imponer una contribución directa a las personas que tenían un cargo en la administración pública y cobraban de ella, o bien a aquellas que por realizar una función autorizada por el rey o un representante de la Corona disfrutaban de una entrada de dinero cobrada a los que requerían de sus servicios. Las cantidades a aportar oscilaban bastante, según la importancia del cargo y de los beneficios que se presumía les reportaba, y asi, por ejemplo, pagaban 40 ducados los escribanos de millones de cabezas de partido, 30 ducados los corregidores, asistentes, jurados, veinticuatros, etc. También debían contribuir los médi$\cos$, cirujanos, barberos con título de protomedicato, notarios, procuradores, alguaciles y abogados titulados ${ }^{33}$. Para conseguir una mayor recaudación, el Consejo estipuló que además

"en la Corte y demás ciudades, villas y lugares del reino, todas las personas de cualquier estado, calidad y preeminencia que tuvieren coche y calesa con tiro de dos o tres mulas o caballos, paguen 100 ducados de vellón; los de tres mulas y un caballo o cuatro mulas, 200 ducados; los de una mula o caballo, 50 ducados. Si se tuviera más de un coche sólo se pagaría por uno y quedaban exceptuados los eclesiásticos y los caballeros de la orden de San Juan en el caso que llevaran dos mulas o caballos; si llevaran cuatro han de pagar 200 ducados" ${ }^{34}$.

Como el ingreso del dinero ofrecido en el donativo era urgente y no se disponía de fondos en depósito, y además la recaudación de arbitrios lle-

Ibidem, documento 47.

A.M.S., Sección $4^{\text {a }}$, Escribanías de Cabildo, tomo 13, documento 51.

Ibidem. 
vaba tiempo, no quedaba otra solución que pedir a unos especialistas en estos tipos de operaciones, vecinos de la ciudad, un adelanto de las cantidades, las cuales les debían ser devueltas con el interés correspondiente.

El ayuntamiento era contrario al pago de estos intereses alegando que naturalmente hacían subir más de lo ofrecido la cantidad a pagar por los vecinos y además implicaba que las devoluciones a los prestamistas finalizasen bastantes años después de haberse realizado el donativo. Una dificultad añadida: no siempre había un particular dispuesto a adelantar la cantidad al ayuntamiento, dado el desorden del sistema contributivo y las dificultades que la mayoría de las veces generaba la cobranza de cualquier adelanto.

En todo caso, cada vez que el ayuntamiento ofrecía un donativo, a la vez que era autorizado a adoptar las medidas pertinentes para conseguir su importe (sobre todo la imposición de arbitrios), el Consejo de Castilla le señalaba la necesidad de solicitar el adelanto a algún particular pagando intereses (a daño) durante el tiempo que se tardase en restituir el principal de la deuda. El ayuntamiento buscaba a alguno de estos prestamistas profesionales, pero en el caso de no hallarse a nadie dispuesto se iba pagando el donativo conforme se iba recaudando la nueva imposición.

Si algún particular aceptaba hacer el adelanto, entonces se le entregaba una Real Cédula con las condiciones del préstamo, que debían ser aceptadas formalmente antes de hacer la entrega del dinero al ayuntamiento.

Durante el reinado de Carlos II hubo que recurrir al adelanto por vez primera en 1665, para cumplir con el donativo hecho a su antecesor, Felipe IV, en 1664, pues con los arbitrios impuestos para conseguir la suma sólo se recaudaron 30.000 ducados, de modo que, como urgía la entrega del total de la cantidad, fue necesario que alguien anticipara los 120.000 restantes.

Se ofrecieron a ello Pedro Palomino y varios vecinos más de la ciudad, por lo que la reina gobernadora, Mariana de Austria, les concedió una Real Cédula con los requisitos, figurando Palomino como "suplicante" (representante del grupo de arrendatarios) y el resto como "partícipes". Las normas, de obligado cumplimiento, eran muy rígidas, destacando entre ellas las siguientes:

1) Los arrendadores (suplicante y partícipes) devengaban un interés que no podía superar el $10 \%$.

2) Los arrendadores no debían interesarse por el empleo del dinero.

3) Cada año se iría extínguiendo parte del principal y los intereses, los dos al mismo tiempo, cobrándose ambos de los mismos arbitrios concedidos a la ciudad. 
4) Para la cobranza y administración, hasta que todos los partícipes se hubiesen resarcido de la cantidad entregada y sus intereses, serían beneficiarios de todos los derechos de la Real Hacienda en los arbitrios, que no podían dedicarse para otros pagos.

5) El suplicante y los partícipes se harían cargo en prorrateo de las cantidades que les conviniesen.

6) El suplicante y los partícipes podían renovar, con causa o sin ella, al receptor o guardamayor y proponer en su lugar a otros, que debían ser nombrados por el asistente como administrador de los arbitrios.

7) El suplicante debía declarar los nombres de los partícipes y las cantidades de cada cual, extremos que debían ser aceptados por el rey. A Pedro Palomino, como suplicante, se le concedió la facultad de otorgar a cada partícipe una escritura donde debía figurar la cantidad entregada como principal y los intereses de la deuda.

8) La deuda se pagaba de seis en seis meses por mitad.

9) De esas cantidades se descontaban los gastos, los costos de administración y los derechos del $4 \%$ destinados a la Cámara de Rentas.

10) Del resto de los ingresos se abonarían a los partícipes (el suplicante era a la vez partícipe) primero los intereses, sin que fuera necesario por cada abono otro justificante que el despacho de la escritura. En estas escrituras se reflejaba el ajuste semestral de las cuentas, bajando del total el $4 \%$ de costas de administración.

11) El dinero que restaba se habia de emplear en ir extinguiendo el principal. Si a los cuatro días de haber una cantidad para extinguir el principal no acordasen entre ellos una decisión, se les cobrarían intereses para que así actuasen otra vez con prontitud, poniéndose mientras tanto la cantidad en el depositario por cuenta y riesgo de los partícipes, tanto el principal como los intereses.

12) $\mathrm{Ni}$ el suplicante ni los partícipes tenían preferencia en la cobranza por la fecha de entrega de su parte del adelanto.

13) Tampoco debían pagar los arrendatarios ningún tipo de derecho, incluidas las medias annatas, aunque fuera ésta la costumbre.

14) Los partícipes gozarían de los intereses del adelanto desde el 1 de enero de 1666 con una tasa del $10 \%$ hasta la completa devolución del principal ${ }^{35}$.

35 A.M.S., Sección 19. Privilegios, carpeta 10, documento 188. 
En el donativo de 70.000 ducados del año 1671, la Corona facultó al ayuntamiento para que buscase 50000 ducados (fue la primera cantidad ofrecida, aunque después se aumentó con 20.000 más) con "premio" del $10 \%$ anual. Benito Antonio de Mañas ofreció sólo 30.000 ducados a resarcir mediante el cobro de dos maravedíes en cada libra de carne. El monarca pidió el parecer a la ciudad ( «lo que mejor convenga al servicio y para los alivios de los contribuyentes»), que no se mostró muy conforme con la decisión real, ya que se creía capacitada para hacer frente al donativo sin necesidad del pago de los intereses. En el fondo el ayuntamiento quería que se derogase la concesión, pues el rey había jurado aceptar la decisión al respecto del cabildo de la ciudad. Presentada esta petición por el asistente de Sevilla, Carlos II respondió que ante todo se debía cumplir lo antes posible con la suma ofrecida "como conviene al Real Servicio de S.M. ${ }^{36}{ }^{\text {». }}$.

Mañas anticipó los 30.000 ducados en marzo de 1671 y en mayo siguiente hizo lo mismo con otros 20.000 , también con un interés del $10 \%$, sobre el arbitrio de medio real en cada arroba de vino. Ya sólo faltaba buscar los 20.000 ducados restantes, que el ayuntamiento se esmeró en encontrar pero sin éxito, por lo que al final hubo que pedirlos a los mismos regidores del ayuntamiento con caudales disponibles ${ }^{37}$.

De nuevo le correspondió a Mañas adelantar parte de los 75000 ducados ofrecidos en 1671. Una Real Cédula de 4 de febrero de 1672 aceptaba el anticipo de 50.000 ducados al contado y como fórmula de pago los diferentes arbitrios vistos en el apartado anterior. Los capitulares seguían sin estar de acuerdo y solicitaron al rey que anulara aquellos arbitrios y en su lugar nombrara diputados para buscar los 50000 ducados. La petición no fue aceptada y Benito de Mañas anticipó la suma ${ }^{38}$.

Nuevamente tuvo que recurrir el ayuntamiento a pedir "a daño" los 75000 ducados ofrecidos en 1674, pues en una Real Cédula de 1 de mayo de ese año Carlos II ordenó al asistente de Sevilla, Carlos de Herrera Ramírez de Arellano, preocuparse de la entrega del dinero en tres veces entre los años 1674 y 1675 , al tiempo que autorizaba al ayuntamiento a pedir el adelanto con un interés del $10 \%$. Finalmente no hubo necesidad de pagar el donativo por tercios, pues el vecino de Sevilla Manuel de Herrera hizo un empréstito por el total de la cantidad y el abono pudo hacerse completo el primer año a un interés del $8 \%$, con el

\footnotetext{
${ }^{36}$ A.M.S., Sección 10" Actas Capitulares, siglo XVII, tome 145. Ibidem.

lbidem.
} 
consiguiente ahorro de un $2 \%$ a los vecinos, calculado en unos 560000 maravedies ${ }^{39}$.

Pero no siempre aparecian particulares para hacer estos adelantos. Así, para los donativos de 100.000 escudos de 1674 y los 80000 de 1676, a pesar de estar autorizados por el Consejo de Castilla y ofrecidos por el ayuntamiento, no se encontró a ningún prestamista, por lo que hubo de abonarse conforme se iba recaudando.

En el último donativo del reinado de Carlos II, el sistema hacendístico estaba ya muy agotado, por lo que era muy difícil encontrar quien prestase dinero aun con intereses. Para completar las dos compañías ofrecidas en 1690 se necesitaron 10.000 escudos cargados al arbitrio de los dos maravedíes por cada libra de carne, que por otro lado ya estaba empeñado con anterioridad, por lo que nadie quiso comprometerse al adelanto. Finalmente, el vecino de la ciudad Martín Rico ofreció el préstamo al 5\%. Cuando en 1692 hubo que enviar otra compañía que costaba otros 10.000 escudos, Rico, que sólo había cobrado 7.000 de los 10.000 prestados, se negó a hacer otro nuevo adelanto. No obstante, apareció un nuevo prestamista, que, como la venta de la carne no daba para nada más, se cobraría gravando la entrada de la nieve procedente de Ronda. Aunque hubo muchas quejas por parte de los capitulares, la fórmula fue aceptada por el rey ${ }^{40}$.

En la ciudad de Sevilla, el asistente era el encargado de toda la gestión de los donativos, desde la asignación hasta la entrega a la autoridad superior. Pero para llevar a cabo todos los trámites era necesario el nombramiento de una serie de personas para realizar las labores de recaudación, contaduría, guarda y posterior entrega al asistente. También era corriente designar, de entre todos los capitulares, una comisión encargada de elaborar las normas para la gestión, tramitar la correspondencia y vigilar el normal desarrollo de la recaudación de arbitrios y de la devolución de las cantidades adelantadas (cuestión problemática, pues el rey era contrario a sobrecargar los donativos con gastos que disminuyeran su ingreso efectivo, y por lo tanto no quería que a estos caballeros se les asignara salario).

A este respecto, para la cantidad de 150.000 ducados, ofrecida en 1664, pero gestionada ya en tiempos de Carlos II, la reina regente ordenó al asistente que sólo nombrase a los siguientes cargos: un guardamayor

39 Ibidem.

40 Ibidem. 
(para vigilar que no se hiciera fraude en los arbitrios), un receptor, un contador (encargado de llevar los libros con los asientos de las cantidades recibidas y de las devoluciones hechas a los arrendatarios del préstamo, tanto del principal como de los intereses) y un depositario general, que fue quien recibió los 150.000 ducados de los prestamistas y quien confeccionó las licencias mediante escrituras firmadas por el asistente con las cantidades entregadas por cada uno. A estos cargos se les fijaba un salario que podía oscilar entre un $3 \%$ sobre el total de la cantidad recaudada para el guardamayor y un $8 \%$ para el receptor ${ }^{41}$.

También se solía nombrar, como se ha visto anteriormente, a unos diputados, elegidos entre los caballeros capitulares, encargados de vigilar la correcta gestión del donativo, bien controlando a los encargados de recaudar y guardar los arbitrios, o bien para encontrar a posibles defraudadores, en número variable (era un cargo de renovación anual, aunque solía ser prorrogado por otro año más, no pasando nunca del máximo de dos). Así, para los 75.000 ducados ofrecidos en 1671 , se nombraron dos caballeros veinticuatro y un jurado,

"sacando los gastos, costas y salarios según lo tuviere conveniente y señalare la dicha ciudad y de la dicha diputación y se podrán hacer los acuerdos que conviniere al cobro, imponiendo penas de comisión y otros contra los defraudadores de dichos arbitrios" ${ }^{42}$.

Sin embargo, para el otro donativo de 70.000 ducados del mismo año fueron nombrados dos caballeros, veinte regidores y otros caballeros de distintos cargos para

"que por voto secreto eligieran a los que hubieran de administrar el donativo con el asistente, sin cobrar salario ni incluso el contador o el receptor, y los diputados que salgan elegidos han de tener libro de cuentas y el nombramiento se hacía por un año».

Al asistente, conde de Lepe, no le parecía bien por el decoro de la ciudad que los caballeros dejasen de cobrar salario y así se lo hizo saber al cabildo, el cual contestó que tenía la obligación de conseguir el mayor alivio de los vecinos que debían pagar los arbitrios, pues ya debia hacer frente a los sueidos para el receptor, guardamayor y algunos más que intervenían en las libranzas de los adelantos ${ }^{43}$. Aunque parece que al

\footnotetext{
A.M.S., Sección ta, Privilegios, carpeta 10, documento 188.

Ibidem, documento 192.

A.M.S., Sección 10, Actas Capitulares, siglo XVIi, tomo 145.
} 
final hubo de poner salario a los diputados, el ayuntamiento optó por nombrar como contador y receptor a los mismos que estaban ocupados en otros impuestos con sueldo estipulado, pero como el prestamista Mañas tenía facultad para nombrar estos cargos, la hizo valer para designar como receptor a una persona de su confianza ${ }^{44}$.

En todo caso era el asistente el que en última instancia recibía el dinero de las cantidades adelantadas "a daño" o bien el procedente de la recaudación de los arbitrios. A continuación entregaba la suma correspondiente a la institución que iba a hacer uso de ella (como el asistente Carlos Ramírez de Arellano, que en 1672 entregó al representante de la Armada, Juan Ábalos, 56.000 ducados, parte de los 70.000 ofrecidos en 1671 , lo recaudado hasta entonces), o bien (lo que era más corriente) al presidente del Consejo de Hacienda como responsable último ${ }^{45}$.

Como siempre se le recordaba, el asistente no podía intervenir en las cuestiones internas de los arrendadores cuando el monarca les había facultado mediante el correspondiente contrato a imponer unos arbitrios o arrendar unas tierras. Sin embargo, en Alcalá de Guadaira el teniente de asistente quiso entender sobre las quejas de los vecinos que utilizaban las tierras comunales para pastos (por ser criadores de ganado que abastecían de carne a la ciudad) y que las habían visto arrendadas para conseguir la cantidad correspondiente al donativo de 60.000 ducados de 1662, por lo que el alcalde de la villa presentó una queja ante la Real Audiencia, pues el teniente de asistente, para fiscalizar al ayuntamiento, preguntaba sobre la administración que se había hecho del asiento de 40.000 reales de los arrendadores, y además afirmaba que las dehesas se habían ofrecido a unos precios muy bajos para beneficiar a los vecinos poderosos cuyos ganados las estaban dejando sin pastos, por lo que hubiera sido más conveniente repartir el donativo entre los vecinos de la villa y respetar el uso de los propios y baldíos ${ }^{46}$.

Impedir el fraude era otra función importante dentro de la recaudación de los arbitrios para así efectuar la devolución a los prestamistas lo antes posible. Por ello, el Consejo daba potestad al asistente para «imponer las penas de comisos y pecuniarias que tuviere por conveniente y hacer las aplicaciones y ejecuciones necesarias a beneficio y aumento del rendimiento del arbitrio" ${ }^{47}$.

44 Ibidern.

45 A.M.S., Sección 19, Privilegios, carpeta 162, documento 406.

46 Ibidem, carpeta 28, documento 407

47 A.M.S., Sección 19, Privilegios, carpeta 10, documento 188 
El tiempo de duración de la imposición de los arbitrios a los vecinos o del arrendamiento de las tierras comunales era un asunto a tener cuenta, y asi en las cédulas que emitía Carlos II se cuidaba siempre de hacer figurar este detalle, calculándose el suficiente para poder recaudar el dinero. En las ocasiones que habia duda sobre el tiempo necesario, aunque se señalaba el plazo, se añadía la frase "o menos tiempo si se pagaba antes el anticipo o más, el que hiciera falta hasta liquidar la deuda" ${ }^{48}$.

Para el donativo de 150.000 ducados concedido en 1664, el tiempo previsto era de cinco años "más o menos o el tiempo que fuera necesario», pero como el plazo no era fácil de cumplir según el estado económico de la ciudad, el contador del donativo daba cuenta todavía en 1672 del resultado de la recaudación de los arbitrios, informando además que aún se debían los salarios de los encargados de la gestión económica ${ }^{49}$.

Algo parecido ocurrió con los arbitrios de los 80000 ducados de 1643 , pues todavía en 1684 se pasaban las cuentas de su rendimiento; o con los 60000 ducados de 1662 , ya que en 1690 se estaban pagando las libranzas de las cantidades tomadas «a daño» 50 .

El plazo concedido para el donativo de 1671 de 75.000 ducados fue de dos años y medio "o menos si antes los hubiera rendido los arbitrios", pero en 1673 el gobierno seguía pidiendo los 25.000 ducados que faltaban por ingresar, respondiendo el ayuntamiento que cada vez se recaudaba menos debido al aumento del fraude y al descenso del consumo producido sobre todo por el aumento de los impuestos y de los descuentos que se hacían para los gastos que ocasionaba la gestión, además de la exención del estado eclesiástico, que no pagaba esta contribución ${ }^{51}$.

Tampoco estaban mucho más claras las cuentas de las cantidades que se extraían de los propios y baldíos. Cuando en 1692 se estableció el rompimiento y arrendamiento de la dehesa de Tablada para reponer la compañia a caballo que faltaba de las dos ofrecidas en 1690 , se hizo por espacio de cuatro años, siendo lo recaudado los dos primeros años para atender a los gastos de la citada compañía y los otros dos para invertir en la edificación de la iglesia de San Fernando, debiendo cesar el rompimiento obligatoriamente al finalizar ese plazo. Pero la dehesa estaba ya arrendada para proveer la cantidad asignada a la ciudad para la construcción de un puente en Toledo. Aun así fue sacada a subasta pública, a pesar de que sus arrendadores la

48 A.M.S.,Sección 12, Privilegios, carpeta 10, documento 185.

49 A.M.S., Sección 10 , Actas Capitulares, siglo XVII, tomo 145.

50 A.M.S., Sección 1a, Privilegios, carpeta 19, documento 69.

51 A.M.S., Sección 10a, Actas Capitulares, siglo XVII, tomo 146. 
tenían ya sembrada para la siguiente cosecha, con la condición de recibir éstos una indemnización por esa eventualidad a cargo de los nuevos arrendadores, circunstancia que no se produjo al ser muy poco lo ofrecido en la subasta, decidiendo el ayuntamiento no alquilarla hasta el año siguiente ${ }^{52}$.

Al asistente le correspondió también la recaudación de la cantidad mandada cobrar en 1684, tenida asimismo como donativo, a todos los funcionarios y personal con título. En 1689 no había dado todavia el resultado previsto a pesar de haber utilizado el asistente medios suaves para lograr que hicieran el ingreso y evitar el apremio a los contribuyentes. Ante esta situación, decidió que se les descontara de la blanca de carne (gratificación que tenían ciertos funcionarios y que consistía en comprar la carne más barata) o directamente de sus sueldos ${ }^{53}$.

A lo largo de este trabajo se han podido ir viendo todas las peculiaridades de los donativos concedidos al rey Carlos II y de otros pendientes de su antecesor Felipe IV, tratados desde su ofrecimiento hasta su devolución a los prestamistas.

Como se ha observado, la ciudad de Sevilla y las villas de su partido no ponían objeciones a las aportaciones que debían hacer para completar las cantidades asignadas al reino de Sevilla, sino que más bien respondían a las peticiones reales con generosidad pese a su penosa situación, aunque tuvieran que devolver a los prestamistas los adelantos de varios donativos al mismo tiempo.

La devolución de las cantidades adelantadas «a daño" por los prestamistas obligaba a aumentar la recaudación de los arbitrios pues el donativo debía entregarse completo y sin descuento de gastos e intereses, por lo que al final la suma se incrementaba considerablemente. Era este un problema sin solución a causa de la carencia de fondos del municipio.

Al final del reinado de Carlos II, el sistema hacendístico español daba síntomas del mayor agotamiento. Sevilla, una ciudad hundida demográfica y económicamente, ni tenía dinero para adelantar ni tenía facilidad para encontrar prestamistas ni sabía cómo aumentar los impuestos sobre una población ya muy agobiada por una desaforada presión fiscal. $Y$, sin embargo, los donativos siguieron pidiéndose y la modalidad sobrevivió al cambio de dinastía.

52 A.M.S., Sección 10ª Actas Capitulares, siglo XVII, tomo 155.

53 Ibidem, tomo 154. 